\title{
Growth and yield of corn forage intercropped with marandu grass in an agrosilvopastoral system with eucalyptus
}

\section{Desenvolvimento e produtividade da forragem do milho consorciado com capim-marandu em sistema agrossilvipastoril com eucalipto}

\author{
Miguel Sales Domingues ${ }^{1 *}$; Cristiana Andrighetto ${ }^{2}$; \\ Gelci Carlos Lupatini; Gustavo Pavan Mateus ${ }^{3}$; Aline Sampaio Aranha ${ }^{4}$; \\ Rafael Keith Ono ${ }^{5}$; Mayara Mayumi dos Santos Shiguematsu ${ }^{6}$; \\ Polyana Vellone Giacomini ${ }^{6}$; Bianca Midori Souza Sekiya ${ }^{7}$
}

\begin{abstract}
Corn and grass intercropping is an interesting practice, and forage plants belonging to the genus Urochloa are the most commonly used in these situations. These plants show excellent adaptation to low-fertility soil, easy establishment, considerable biomass production, as well as being an important competitor with weeds. In agrosilvopastoral systems, the yield of corn crops grown together with trees is hindered due to the reduced radiation incidence caused by tree shading. This study aimed to evaluate corn growth, light interception, and chlorophyll content when intercropped with marandu grass in an agrosilvopastoral system with one and three eucalyptus rows, and compare them with plants under full sun. The experiment was conducted in Andradina - SP (Brazil). Treatments consisted of intercropping with no eucalyptus (plants under full sun: control), one system with one eucalyptus row and another with three rows. We also assessed the effect of five distances between corn plants and eucalyptus trees $(2,4,6,8$, and $10 \mathrm{~m})$. Between eucalyptus rows, corn plants were intercropped with marandu grass. The analyzed variables were corn plant height, ear height, chlorophyll content index, light interception, dry matter, and fresh and dry forage weights. The experimental design was a randomized block in a factorial scheme plus a control, with four repetitions. Tree arrangements had no influence on corn forage, dry matter, plant height, or ear height. Lower results of yield, dry matter, plant height, and ear height were observed for plants spaced $2 \mathrm{~m}$ from trees. In the first two evaluations, significant differences of light interception were found for the different distances. Neither tree arrangements (one and three rows) nor the distances from the trees had any impact on corn heights, with no difference between control and the agrosilvopastoral systems. Neither plant distances from trees nor tree arrangements had an influence on chlorophyll content index of corn plants, with no difference between control and the treatments. As a
\end{abstract}

\footnotetext{
${ }^{1}$ M.e em Ciência e Tecnologia Animal, Universidade Estadual Paulista "Júlio de Mesquita Filho", UNESP Dracena, Ilha Solteira, SP, Brasil. E-mail: domingues_ms@yahoo.com.br

2 Prof., UNESP, Faculdade de Ciências Agrárias e Tecnológicas, FCAT, Câmpus de Dracena, Dracena, SP, Brasil. E-mail: cristiana@dracena.unesp.br; lupatini@dracena.unesp.br

${ }^{3}$ Pesquisador, Agência Paulista de Tecnologia dos Agronegócios, APTA, Polo Regional de Desenvolvimento dos Agronegócios do Extremo Oeste, Andradina, SP, Brasil. E-mail: gpmateus@apta.sp.gov.br

${ }^{4}$ Discente, Curso de Doutorado, Programa de Pós-Graduação em Zootecnia, Faculdade de Medicina Veterinária e Zootecnia, FMVZ, UNESP, Botucatu, SP, Brasil. E-mail: aline.aranha@outlook.com

5 Pós-Doutorando, Empresa Brasileira de Pesquisa Agropecuária Suínos e Aves, Embrapa Suínos e Aves, Concórdia, SC, Brasil. E-mail: keith@zootecnista.com.br

${ }^{6}$ Discente, Curso de Zootecnia, FCAT, UNESP, Câmpus de Dracena, Dracena, SP, Brasil. E-mail: mayumishigue@hotmail.com; polyana.giacomini@hotmail.com

${ }^{7}$ Discente, Curso de Engenharia Agronômica, FCAT, UNESP, Câmpus de Dracena, Dracena, SP, Brasil. E-mail: bia_souza_ sekiya@hotmail.com

* Author for correspondence
} 
result, corn growth and forage yield under agroforestry systems are similar in arrangements of 1 and 3 eucalyptus rows (15-month-old trees) and under full sun. However, corn dry matter contents were lower in systems containing trees. Intercropping corn and marandu grass in a system without trees increased light interception at harvest time, indicating a larger soil coverage. Corn forage yield and dry matter content were lower when plants were $2 \mathrm{~m}$ apart from eucalyptus trees since this condition provided a lower amount of light and greater competition for water and nutrients.

Key words: Crop-livestock-forest integration. Light interception. Shade. Urochloa brizantha. Zea mays.

\section{Resumo}

O uso do cultivo de milho com capim é interessante no consórcio, sendo as forrageiras do gênero Urochloa são as mais utilizadas, destacando-se por apresentar excelente adaptação aos solos de baixa fertilidade, fácil estabelecimento, considerável produção de biomassa e importante competidora com espécies daninhas das culturas anuais. Nos sistemas agrossilvipastoris a produtividade do milho cultivado sob árvores é influenciada em função da diminuição da radiação causada pelo sombreamento. O objetivo do trabalho foi avaliar o desenvolvimento, interceptação luminosa e índice de conteúdo de clorofila (ICC) do milho consorciado com capim-marandu em sistema agrossilvipastoril com 1 linha de eucalipto, 3 linhas de eucalipto e a pleno sol. O experimento foi conduzido na APTA - Andradina, SP e os tratamentos foram: sem eucalipto (pleno sol: controle), sistemas com eucalipto (1 e 3 linhas) e dentro destes, cinco distâncias em relação às árvores $(2,4,6,8$ e $10 \mathrm{~m})$. Entre os renques de eucalipto foi utilizado o sistema de integração com o milho consorciado com capim-marandu. Foram avaliadas as seguintes características produtivas do milho: altura de planta, altura de inserção de espiga, ICC, interceptação luminosa, produção de massa verde, matéria seca e massa seca de forragem do milho. $\mathrm{O}$ delineamento experimental foi em blocos casualizados em arranjo fatorial com tratamento adicional (controle) tendo quatro repetições. A produtividade da forragem de milho, matéria seca, altura das plantas na colheita e altura de inserção de espiga não foram influenciadas pelos arranjos de árvores. À distância de $2 \mathrm{~m}$ em relação às árvores apresentou menores valores de produtividade, matéria seca, altura na colheita e altura de inserção de espiga. Houve diferença para os valores de interceptação luminosa no milho entre as distâncias nas duas primeiras avaliações. As alturas do milho não foram afetadas pelas distâncias das árvores, nem pelos arranjos de árvores (1 e 3 linhas) e não houve diferença entre controle e sistemas agrossilvipastoris. Não houve diferenças no ICC do milho nas distâncias em relação às árvores, nem entre os arranjos (1 e 3 linhas) e também não houve diferenças entre controle e sistemas agrossilvipastoris. Conclui-se que o desenvolvimento e produtividade da forragem do milho em sistemas agrossilvipastoris são semelhantes em arranjos de 1 e 3 linhas de eucalipto com 15 meses e a pleno sol, com exceção do teor de matéria seca que é menor nos sistemas com árvores. O consórcio do milho com o capim-marandu, em sistema sem árvores, apresenta maior interceptação luminosa na colheita do milho indicando maior cobertura do solo. A produtividade e o teor de matéria seca de forragem do milho são menores quando o milho está a $2 \mathrm{~m}$ das árvores de eucalipto, em função da menor quantidade de luz e competição por água e nutrientes.

Palavras-chave: Integração lavoura-pecuária-floresta. Interceptação luminosa. Sombreamento. Urochloa brizantha. Zea mays.

\section{Introduction}

Brazil is among the largest corn producers worldwide, totalizing 79,905 million tons and 15,801 million ha planted area (harvest and interimharvest). The State of São Paulo was responsible for 753.8 thousand ha in the 2013/14 season, which resulted in 31,653 million tons in the first harvest (or summer seeding) and 48,253 million tons in the second harvest (or interim) (CONAB, 2014).

Corn is commonly used in forest intercropping systems because it is simple to cultivate. Due to the economic potentialities and the total area planted yearly, corn and eucalyptus are two important plants for Brazil; therefore, a simultaneous cropping in the 
same area should be seen as a study hypothesis, especially in regions of high agroforestry potential (MACEDO et al., 2006), as is the case of the southcentral region of the country.

Intercropping marandu grass (Urochloa brizantha) and corn is also a good alternative to recover degraded pastures while producing efficiently (NEVES NETO et al., 2015). One of the advantages of using corn with grass is competition since tall corn plants exert a suppression effect on the other species. Corn-ear insertion height allows harvesting without any trouble since harvest cuts at higher platform heights decrease clogging risks (ALVARENGA et al., 2006).

According to Oliveira (2001), the forage species belonging to the genus Urochloa are generally intercropped with corn. These plants stand out for adapting well to low-fertility soils, establishing easily, and producing a considerable biomass throughout the year, besides providing an excellent vegetal cover. They are also considered important because of their aggressiveness and resistance against weeds of annual crops.
However, one of the challenges of agrosilvopastoral systems is the effect plant shading exert on corn growth. According to Perin et al. (2011), lightness is probably the most important factor to consider in these systems since trees may intercept part of the incident radiation, restricting light to the plants understory and, consequently, reducing their growth.

We hypothesized that, in agrosilvopastoral systems, trees can influence corn forage growth. Thus, this study aimed to evaluate the growth, chlorophyll content index, light interception, and forage yield of corn plants associated with marandu grass in an agrosilvopastoral system with eucalyptus.

\section{Material and Methods}

The experiment was conducted at the São Paulo State Agency for Agribusiness Technology (APTA) - Far West Regional Center - in Andradina (2053'46" S latitude, 51 ${ }^{\circ} 22^{\prime} 46$ " W longitude, and 405-m altitude), in the western São Paulo. Climate data such as rainfall, maximum, minimum, and mean temperatures were gathered from a weather station located at APTA (Figure 1).

Figure 1. Rainfall $(\mathrm{mm})$ and minimum, maximum, and average temperatures $\left({ }^{\circ} \mathrm{C}\right)$ per month (from November 2013 to June 2014). Andradina-SP, Brazil.

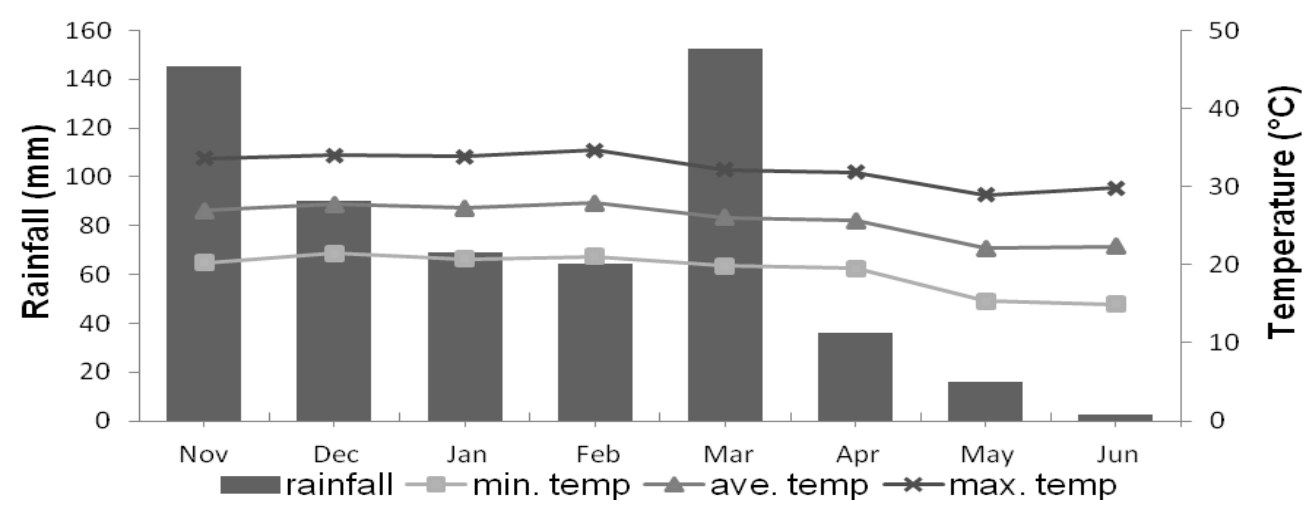


According to Köppen's classification, local climate is classified as an $A w$ type, which stands for tropical humid with rainy summers and dry winters, the coldest month with mean temperatures above $18{ }^{\circ} \mathrm{C}$. Local soil is classified as a dystrophic Red Yellow Argisol, with a sandy surface layer and slope angle of $6 \%$.

Project started in December 2011 by selecting the area and surveying its topography. The project was rolled-out over the first semester of 2012, with treatment choice and stall settling. During the second semester of 2012, soil samples were collected and evaluated; then, the soil was limed and plastered; and treatment delimitation proceeded, so seeding could begin.

In July 2012, the soil was limed based on chemical analyses $(0-20 \mathrm{~cm}$ soil depth), which showed the following attributes: $\mathrm{pH}\left(\mathrm{CaCl}_{2}\right)-4.8$, $\mathrm{OM}-16 \mathrm{~g} \mathrm{dm}^{-3}, \mathrm{P}$ (resin) - $3 \mathrm{mg} \mathrm{dm}{ }^{-3}, \mathrm{~K}^{+}, \mathrm{Ca}^{2+}$, $\mathrm{Mg}^{2+}$, and $\mathrm{H}+\mathrm{Al}-1.9,7.0,5.0$, and $20.0 \mathrm{mmol}_{\mathrm{c}}$ $\mathrm{dm}^{-3}$ respectively, $\mathrm{S}_{-} \mathrm{SO}_{4}^{2-}-1 \mathrm{mg} \mathrm{dm}{ }^{-3}$, and $\mathrm{V} \%$ (base saturation) - 42. Clay, silt, and sand contents were of 107,113 , and $780 \mathrm{~g} \mathrm{~kg}^{-1}$, respectively. A dolomitic limestone (RPTN 80\%) was applied and incorporated at about $1200 \mathrm{~kg} \mathrm{ha}^{-1}$ to elevate base saturation to $70 \%$. Then, agricultural plaster was incorporated at $600 \mathrm{~kg} \mathrm{ha}^{-1}$ in the total area to supply sulfur, as recommended by the Boletim 100 (RAIJ et al., 1997) for the state of São Paulo. Then, terracing, harrowing, plowing, and leveling were performed during the soil preparation.

Eucalyptus clone was I-224 (Eucalyptus urograndis), which has cellulose producing characteristics. They were fertilized with the 04-3016 formula, which was applied to the planting hole at $350 \mathrm{~kg} \mathrm{ha}^{-1}$, being $210 \mathrm{~g}$ per seedling $(8.4 \mathrm{~g} \mathrm{~N}$; $63 \mathrm{~g} \mathrm{P}_{2} \mathrm{O}_{5} ; 33.6 \mathrm{~g}$ of $\mathrm{K}_{2} \mathrm{O}$ ). Planting was conducted in November 2012. A topdressing was performed in February 2013 (37 kg ha ${ }^{-1} \mathrm{~N}, 3 \mathrm{~kg} \mathrm{ha}^{-1} \mathrm{Zn}$, and $2 \mathrm{~kg}$ $\left.\mathrm{ha}^{-1} \mathrm{Bo}\right)$, applying $50 \mathrm{~g}$ urea $(23 \mathrm{~g} \mathrm{~N}), 9 \mathrm{~g}$ zinc sulfate $(1,8 \mathrm{Zn})$, and $12 \mathrm{~g}$ borogran (1.2 g B) around each eucalyptus seedling base. In January 2014, another top-dressing was applied $\left(123 \mathrm{~kg} \mathrm{ha}^{-1} \mathrm{~N}\right)$, spreading $160 \mathrm{~g}$ urea $(73.6 \mathrm{~g} \mathrm{~N})$ around each seedling (known as 'crowning').

As needed, cultural practices were performed aiming to control weeds and provide targeted irrigation for newly planted trees. Replanting was necessary for some areas due to the occurrence of elevated temperatures and hydric deficits during the summer period.

In February and March 2013, the insecticides Karat Zeon (150 mL ha $\left.\mathrm{m}^{-1}\right)$, Match $\left(200 \mathrm{~mL} \mathrm{ha}^{-1}\right)$, and Endossulfan $\left(1 \mathrm{~L} \mathrm{ha}^{-1}\right)$ were applied on eucalyptus plants for beetle control, using a 600-L tractorboom sprayer. Once again, in February 2014, beetle control was reapplied on eucalyptus trees, now using the insecticide mixture Lorsban $(0.8 \mathrm{~L} / \mathrm{ha})+$ Actara $250(0.2 \mathrm{~kg} / \mathrm{ha})$.

The soybean cultivar BMX Potência was seeded in December 2012, using a Semeato seeder (model SAM 200) in four rows, at a density of 20 seeds per meter, and $0.5 \mathrm{~m}$ spacing between rows, totalizing 400,000 seeds.ha ${ }^{-1}$. Mineral fertilization at seeding was with $300 \mathrm{~kg} \mathrm{ha}^{-1}$ of 4-30-16 formulated fertilizer, corresponding to an application of $12 \mathrm{~kg} \mathrm{ha}^{-1} \mathrm{~N}, 90$ $\mathrm{kg} \mathrm{ha}^{-1} \mathrm{P}_{2} \mathrm{O}_{5}$, and $48 \mathrm{~kg} \mathrm{ha}^{-1} \mathrm{~K}_{2} \mathrm{O}$. Topdressing was performed 40 days after sowing with $200 \mathrm{~kg} \mathrm{ha}^{-1}$ of the formula 00-20-20 to improve nutrient levels, as pastures have already degraded the area.

Post-emergence glyphosate-based herbicide (Zapp QI 620) was applied in soybeans at a rate of $1.240 \mathrm{~g}$ ai ha-1 and tank-mix volume of $250 \mathrm{~L}$ $\mathrm{ha}^{-1}$. The application was performed using a tractor sprayer with flat-fan jet nozzles spaced $0.50 \mathrm{~m}$ apart. Together with this, cobalt and molybdenumbased fertilizer (COMO Platinum) was also applied at a dose of $150 \mathrm{~mL} \mathrm{ha}^{-1}$ commercial product. The crops were harvested in May 2013, with an average yield of 35 bags ha-1.

Before establishment, emergent weed control was performed in the post-harvested area, enabling direct corn seeding in December 2013. The area was desiccated using a glyphosate-based herbicide 
(Roundup WG) at a dose of $1440 \mathrm{~g}$ ai ha ${ }^{-1}$ with an application volume of $250 \mathrm{~L} \mathrm{ha}^{-1}$. For this, the tractor sprayer with flat-fan jet nozzles spaced 0.50 m apart was used.

Grass and corn were sown in December 2013. For that, pure and viable seeds of marandu Urochloa brizantha (Syn. Brachiaria brizantha) were used at a density of $8.0 \mathrm{~kg} \mathrm{ha}^{-1}$ within an inter-row spacing of $0.2 \mathrm{~m}$. The direct sowing was made with a Semeato seeder (model SAM 200), pulled by a New Holland tractor (model TL $754 \times$ 4). Afterwards, the commercial corn hybrid BG 7049 (Biogene) was sown, using seeds treated with thiamethoxambased insecticide (Cruiser 350) at a dosage of 300 $\mathrm{mL} 100 \mathrm{~kg}^{-1}$ seeds. To reach a population density of 62,500 plants per hectare, a spacing of $0.80 \mathrm{~m}$ was used between rows. Fertilization was made applying $310 \mathrm{~kg} \mathrm{ha}^{-1} 8-28-16$ formula fertilizer, which corresponds to $24.8 \mathrm{~kg} \mathrm{ha}^{-1} \mathrm{~N}, 86.8 \mathrm{~kg} \mathrm{ha}^{-1}$ $\mathrm{P}_{2} \mathrm{O}_{5}$, and $49.6 \mathrm{~kg} \mathrm{ha}^{-1} \mathrm{~K}_{2} \mathrm{O}$. Additionally, 20 days after corn emergence, topdressing was conducted with $92 \mathrm{~kg} \mathrm{ha}^{-1}$ nitrogen via urea.

Caterpillar control was carried out in January 2014, using a Lambdacyhalothrin-based insecticide (Karate Zeon) at $7.5 \mathrm{~g}^{\mathrm{ai}} \mathrm{ha}^{-1}$, and Lufenuronbased insecticide (Match CE) at $15 \mathrm{~g}$ ai ha-1. Simultaneously, selective Atrazine-based herbicide (Primóleo) was used for broadleaf weed control in both corn and pasture at $2400 \mathrm{~g}$ ai $\mathrm{ha}^{-1}$. The aforementioned insecticides and herbicide were administered using a tractor-boom sprayer with an application volume of $250 \mathrm{~L} \mathrm{ha}^{-1}$.

The experiment was conducted in randomized blocks, in a factorial scheme plus a control [ $(2 \times 5)$ $+1]$. One factor consisted of two agrosilvopastoral systems: one row of eucalyptus trees (2-m spacing between plants, 17 and $21 \mathrm{~m}$ between rows, 196 trees $\left.\mathrm{ha}^{-1}\right)$, three rows of eucalyptus trees (2-m spacing between trees, $3 \mathrm{~m}$ between rows, 17 and $21 \mathrm{~m}$ between sets of trees, 448 trees $\mathrm{ha}^{-1}$ ). The other factor was five different distances between eucalyptus and corn plants $(2,4,6,8$, and $10 \mathrm{~m})$, in addition to a control treatment (no trees, corn plants under full sun exposure). All treatments contained four repetitions. Experimental plots with corn sowing intercropped with marandu grass were $5 \mathrm{~m}$ wide and $10 \mathrm{~m}$ long and were perpendicular to the eucalyptus strips.

The height of corn plants was measured in all experimental plots, using four plants from each treatment $(2,4,6,8,10 \mathrm{~m})$. Plants were measured with a measuring tape from the soil to the insertion point of the last expanded leaf (yellow line). For control, eight plants were measured per plot and an average was calculated. Plant heights were measured every 14 days until flowering.

During flowering, the chlorophyll content index (CCI) was measured using the opposite and below leaves to the first ear, using 10 plants per treatment $(2,4,6,8,10 \mathrm{~m})$. These measurements were taken with an Opti-Science chlorophyll meter (model CCM-200 USA) in a nondestructive method.

Light interception (LI) was monitored using a canopy analyzer and a photosynthetically active radiation meter (AccuPAR model LP-80 PAR/LAI). Readings were made between 11 a.m. and 2 p.m. on days with predominantly clear skies (no or few clouds) every 28 days, from February to May 2014. In each plot, photosynthetically active radiation measurements were taken $\left(\mu \mathrm{mol}\right.$ of $\mathrm{m}^{-2} \mathrm{~s}^{-1}$ ) at three points beneath and above the canopy, at each distance $(2,4,6,8,10 \mathrm{~m})$. For control, measurements were collected at three points above and beneath the canopy, as well as at two random points of the plot, as the lack of trees produced no shade in this group. Afterwards, the light interception was calculated according to Carnevalli (2003), as follows: $\mathrm{LI}=\{1$ - (PAR beneath the canopy/PAR above the forage canopy)\} x 100.

The harvest point of corn forage was defined based on the phenological stage characterized as farinaceous grain, and on the dry matter content of crushed corn plants. At harvest time, the following agronomic characteristics were evaluated: plant height and ear height (from the ground level to the ear insertion point) for each distance. 
For all treatments, corn plants were cut at $0.2 \mathrm{~m}$ to remove shoots of plants along $5 \mathrm{~m}$ row $\left(4 \mathrm{~m}^{2}\right)$, at each distance $(2,4,6,8,10 \mathrm{~m})$. For control, an average of two representative samples was made. These samples were weighed, and some samples were taken for mincing, drying, and subsequent determination of dry matter contents. All the collected material was dried out in a forced circulation oven at $65{ }^{\circ} \mathrm{C}$ for 72 hours.

Statistical analyses were performed through the R statistical software (R CORE TEAM, 2014), using the "fat2.ad.dbc()" function for double factorial from the "ExpDes.pt" package (FERREIRA et al., 2013).

\section{Results and Discussion}

The changes in the planting distance between corn and eucalyptus had no effect on the height of corn plants (Table 1); therefore, the shading caused by the 15-month-old eucalyptus trees had no effect on this crop feature. Moreover, studying an arrangement of $10 \times 4 \mathrm{~m}$ with 24-month-old eucalyptus clones, Macedo et al. (2006) observed that the intercropped corn situated 4.5 and $5.4 \mathrm{~m}$ from the tree rows were taller than those 1.8 and $2.7 \mathrm{~m}$ far from them. It is noteworthy that the trees used here were younger, so they might have shaded less and competed less with the crops, thus not interfering with corn height.

Table 1. Plant heights of corn intercropped with marandu grass in 15-day intervals and chlorophyll content index $(\mathrm{CCI})$ at flowering in an agrosilvopastoral system.

\begin{tabular}{|c|c|c|c|c|c|c|c|c|c|c|}
\hline \multirow{3}{*}{$\begin{array}{l}\text { Evaluations } \\
\text { Distance (m) }\end{array}$} & \multicolumn{8}{|c|}{ Height (cm) } & \multirow{2}{*}{\multicolumn{2}{|c|}{ CCI }} \\
\hline & \multicolumn{2}{|c|}{1} & \multicolumn{2}{|c|}{2} & \multicolumn{2}{|c|}{3} & \multicolumn{2}{|c|}{4} & & \\
\hline & 1 line & 3 line & 1 line & 3 line & 1 line & 3 line & 1 line & 3 line & 1 line & 3 line \\
\hline 2 & 38 & 38 & 58 & 54 & 127 & 119 & 145 & 133 & 52,53 & 44,24 \\
\hline 4 & 46 & 47 & 67 & 74 & 148 & 142 & 148 & 154 & 59,66 & 51,40 \\
\hline 6 & 42 & 49 & 68 & 76 & 126 & 150 & 142 & 169 & 60,16 & 58,66 \\
\hline 8 & 45 & 51 & 65 & 78 & 131 & 140 & 142 & 152 & 52,46 & 55,50 \\
\hline 10 & 44 & 53 & 73 & 70 & 130 & 140 & 147 & 155 & 56,79 & 48,02 \\
\hline
\end{tabular}

P>0,05. Evaluations: $1=01 / 31 / 14 ; 2=02 / 12 / 14 ; 3=02 / 27 / 14 ; 4=03 / 14 / 14$.

Also regarding corn height, both row tree arrangements (1 and 3 ) had no statistical difference, with average heights of 45, 68, 135, and $149 \mathrm{~cm}$ in evaluations $1,2,3$, and 4, respectively. In addition, there were no differences between the control group and the tested agrosilvopastoral systems, with averages of $47,71,135$, and $151 \mathrm{~cm}$ in evaluations $1,2,3$, and 4 , respectively.

At corn flowering, the distances between corn and eucalyptus trees had no influence on CCI (Table 1). Likewise, no differences were found $(\mathrm{P}>0.05)$ between 1- and 3-row arrangements for corn CCI, with values of 56.32 and 51.56, respectively. Again, no differences were found between control and the agrosilvopastoral treatments, with an average CCI of 54.53; hence, tree arrangements had no effect on corn photosynthetic activity. Conversely, after 60 days, Mendes et al. (2013) found lower values of CCI for corn (30 - SPAD Index) for the control treatment (without trees) in relation to the distances of 1, 2, 3, and $4 \mathrm{~m}$ from pau-branco trees (Cordia oncocalyx) in the semi-arid region (Caatinga) of Northeast Brazil. These differences may be attributed to a poorer shading provided by the young eucalyptus trees, what caused no alterations on chlorophyll contents of corn plants in our study.

Table 2 describes the evaluations of corn intercropped with grass at 2, 4, 6, 8, and $10 \mathrm{~m}$ from the eucalyptus trees. From that, we may note that the relationship between the distances and light interception (LI) by corn plants was best expressed by a linear regression in the first evaluation, as seen 
in Figure 2A. The equation shows that increasing the distance from the trees by $1 \mathrm{~m}$, LI increases in $1.69 \%$. In the second evaluation, LI was best described by a cubic equation (Figure 2B), with the lowest value at $2 \mathrm{~m}(75.54 \%)$. In the third and fourth evaluations, no differences in LI were found $(\mathrm{P}>0.05)$ for any of the distances, reaching values of $88.04 \%$ and $90.00 \%$, respectively. This indicates that as the forage grew, the differences in LI for the distances $2,4,6,8$, and $10 \mathrm{~m}$ decreased.

Table 2. Evaluations of corn intercropped with grass at 2, 4, 6, 8, and 10-m distances in an agrosilvopastoral system.

\begin{tabular}{|c|c|c|c|c|c|c|c|c|}
\hline \multirow{2}{*}{ Parameters } & \multirow[b]{2}{*}{ Control } & \multirow[b]{2}{*}{2} & \multicolumn{4}{|c|}{ Distances (m) } & \multirow{2}{*}{$\begin{array}{l}\mathrm{CV} \\
(\%)\end{array}$} & \multirow{2}{*}{$\mathbf{R}$} \\
\hline & & & 4 & 6 & 8 & 10 & & \\
\hline Height $1(\mathrm{~cm})^{1}$ & 49 & 38 & 47 & 46 & 48 & 46 & - & Ns \\
\hline Height $2(\mathrm{~cm})^{2}$ & 74 & 56 & 70 & 72 & 72 & 71 & - & Ns \\
\hline Height $3(\mathrm{~cm})^{3}$ & 135 & 123 & 145 & 138 & 135 & 135 & - & Ns \\
\hline Height $4(\mathrm{~cm})^{4}$ & 153 & 139 & 151 & 155 & 147 & 151 & - & Ns \\
\hline $\mathrm{CCI}^{5}$ & 55.13 & 48.39 & 55.53 & 59.41 & 53.98 & 52.40 & - & Ns \\
\hline LI $1(\%)^{6}$ & 41.07 & 37.73 & 41.11 & 44.49 & 47.87 & 51.26 & 15.86 & $\mathrm{~L}$ \\
\hline LI $2(\%)^{7}$ & 84.60 & 75.55 & 87.27 & 86.43 & 83.27 & 88.07 & 6.80 & $\mathrm{C}$ \\
\hline LI $3(\%)^{8}$ & 89.00 & 86.31 & 88.93 & 89.51 & 87.19 & 88.28 & - & Ns \\
\hline LI $4(\%)^{9}$ & 96.58 & 85.37 & 90.80 & 91.12 & 90.77 & 91.93 & - & $\mathrm{Ns}$ \\
\hline Height at harvesting (cm) & 144 & 124 & 154 & 153 & 144 & 147 & 7.30 & $\mathrm{C}$ \\
\hline Ear height $(\mathrm{cm})$ & 72 & 61 & 83 & 82 & 74 & 78 & 9.02 & $\mathrm{C}$ \\
\hline $\begin{array}{c}\text { Fresh Mass } \\
\left(\mathrm{kg} \mathrm{ha}^{-1}\right)\end{array}$ & 19,474 & 9,642 & 22,989 & 25,127 & 23,531 & 25,673 & 23.33 & $\mathrm{C}$ \\
\hline $\begin{array}{c}\text { Dry Mass } \\
\left(\mathbf{k g ~ h a}^{-1}\right)\end{array}$ & 5,627 & 2,456 & 6,100 & 7,038 & 6,901 & 7,321 & 26.71 & $\mathrm{C}$ \\
\hline Dry Mass Content (\%) & 28.61 & 22.59 & 26.09 & 28.25 & 29.07 & 28.55 & 5.91 & Q \\
\hline
\end{tabular}

CV - Coefficient of variation; R - Regression; Ns - Non-significant; L - Linear; Q - Quadratic; C - Cubic.

${ }^{1} 01 / 31 / 14 ;{ }^{2} 02 / 12 / 14 ;{ }^{3} 02 / 27 / 14 ;{ }^{4} 03 / 14 / 14 ;{ }^{5} \mathrm{CCI}$ - Chlorophyll Content Index at Flowering; ${ }^{6} \mathrm{LI}$ - Light Interception at 02/03/14; ${ }^{7} 03 / 10 / 14 ;{ }^{8} 04 / 02 / 14 ;{ }^{9} 04 / 30 / 14$.

Figure 2. Light interception (\%) of corn intercropped with marandu grass at 2, 4, 6, 8, and 10-m distances from eucalyptus trees in agrosilvopastoral system, measures taken on 02/03/2014 (A) and 03/10/2014 (B).

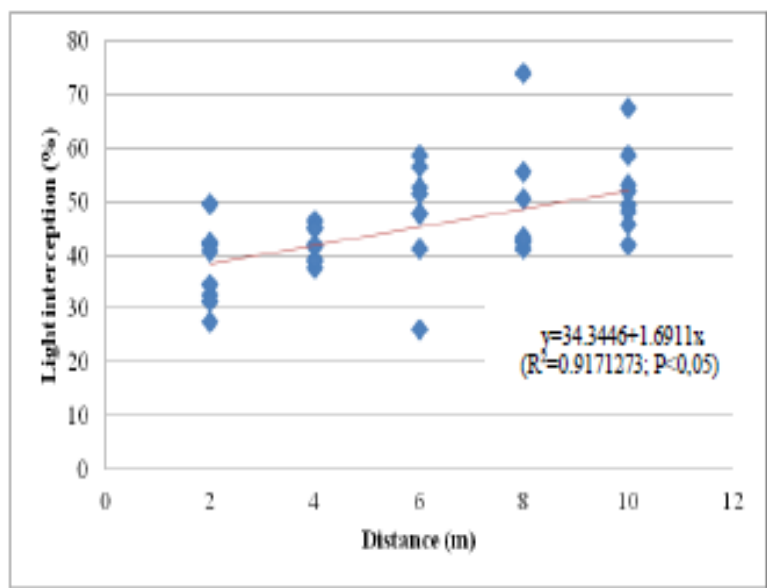

A

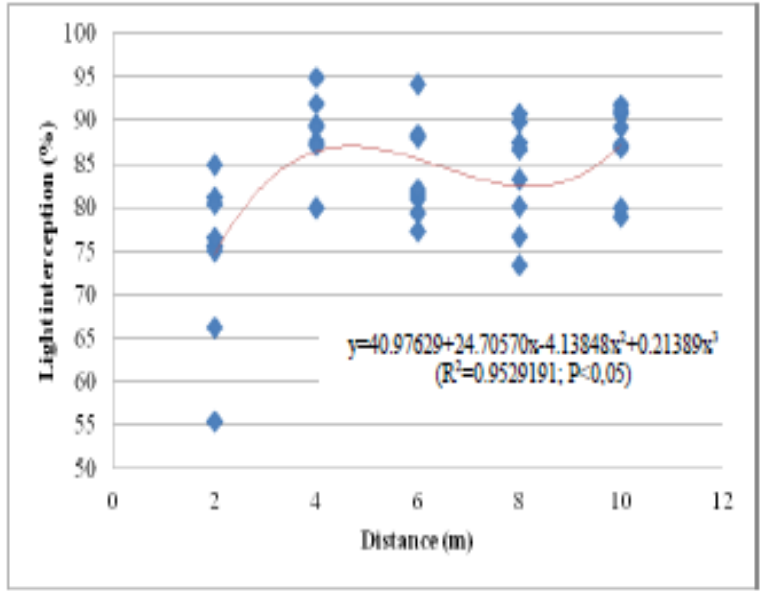

B 
Concerning row arrangements (1 and 3), no differences were found among all evaluations. Additionally, no differences were found in the first, second or third evaluations between control and both arrangements. Yet in the fourth, significant differences were observed $(\mathrm{P}<0.05)$ for LI, being of $96.58 \%$ and $90 \%$ between control and $1-$ and 3-row arrangements, respectively. This outcome demonstrates that the larger soil coverage in systems of corn intercropped with marandu grass without trees might have influenced light interception.

At harvest, corn height was best modeled by a cubic regression (Figure 3), wherein the distance of $2 \mathrm{~m}$ had the shortest plants. The corn plants $4 \mathrm{~m}$ from the eucalyptus trees were the tallest, decreasing as the distance increased to 6 and $8 \mathrm{~m}$.

Figure 3. Corn height at forage harvesting for plants 2, 4, 6, 8, and $10 \mathrm{~m}$ away from eucalyptus trees in an agrosilvopastoral system.

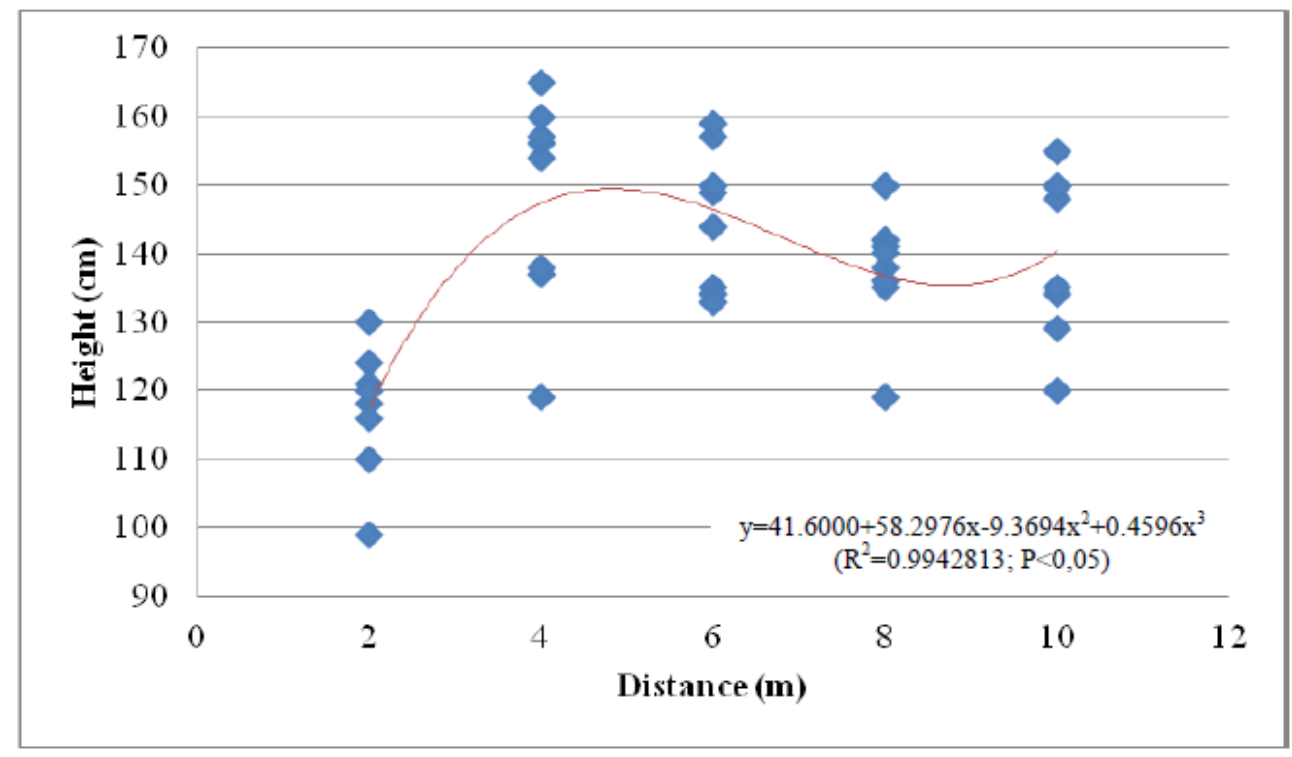

Assessing Catingueiro corn, Mendes et al. (2013) reported plant heights of 156, 172, 178, and $194 \mathrm{~cm}$ at distances of 1, 2, 3, and $4 \mathrm{~m}$ from pau-branco trees, respectively, and when grown under no trees, it was $169 \mathrm{~cm}$. Yet Quintino et al. (2013) obtained plant heights of 170,183,193,157, and $152 \mathrm{~cm}$ at distances of $3,7,11,15$, and $19 \mathrm{~m}$, respectively. If compared to other studies in the literature, the lower heights displayed in Figure 3 can be explained by the fewer rainfall events during the corn growing.

The insertion height of corn ears at forage harvesting (Figure 4) had a cubic relation with the evaluated distances. At harvesting, the lowest heights were found for plants $2 \mathrm{~m}$ far from the eucalyptus trees. Moreover, the treatments presenting the highest plants also exhibited the greatest ear insertion heights.

The arrangements of trees ( 1 and 3 rows) had no influence on the height of corn plants at harvesting (Figure 3) nor on the ear insertion heights (Figure 4) for the studied agrosilvopastoral systems, presenting average heights of 138 and $69 \mathrm{~cm}$, respectively. Moreover, the control showed no differences with the agrosilvopastoral systems in terms of ear insertion height, with averages of 141 , and $71 \mathrm{~cm}$, respectively. 
Figure 4. Corn ear height at forage harvesting for plants 2, 4, 6, 8, and $10 \mathrm{~m}$ away from eucalyptus trees in an agrosilvopastoral system.

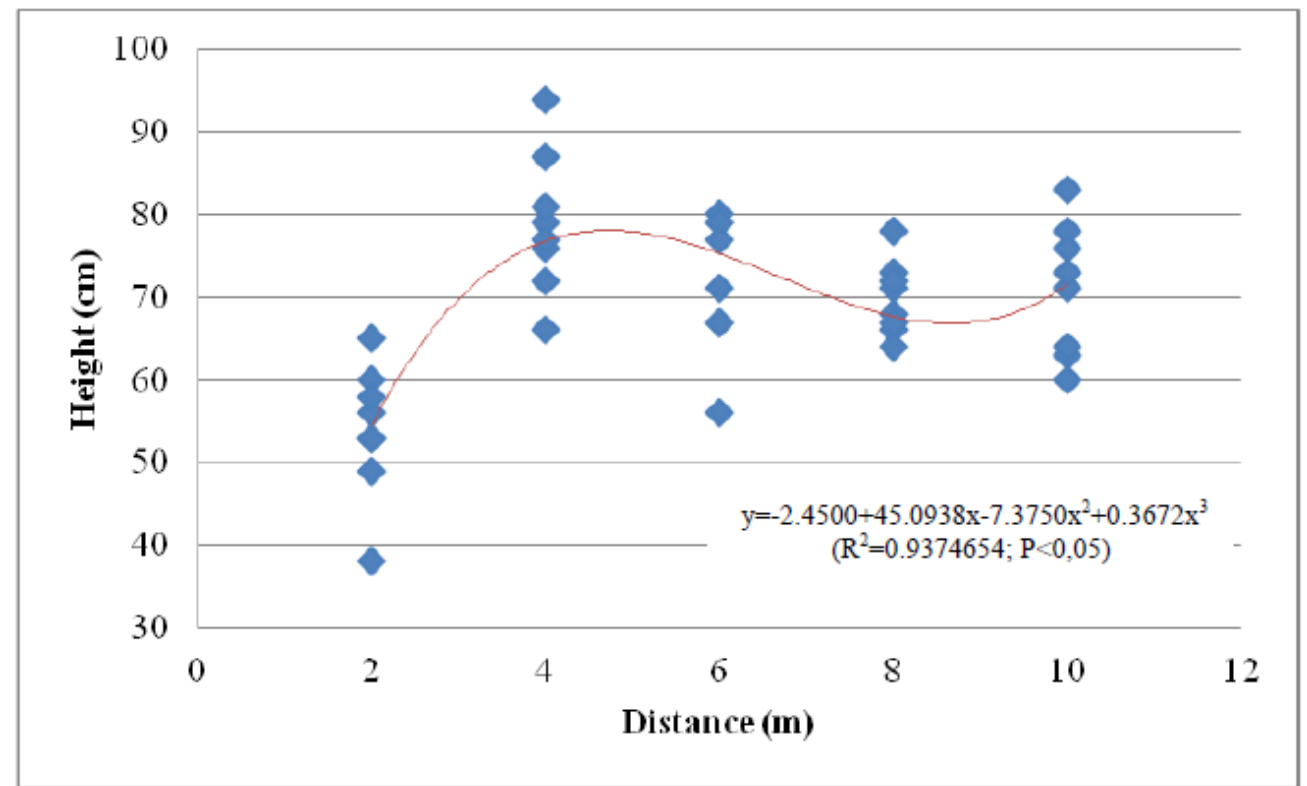

Regarding fresh mass forage, corn plants showed significant differences between the distances from the trees, with a cubic behavior and the lowest yield for plants $2 \mathrm{~m}$ apart from the trees (Figure 5). From the regression equations in Figure 5, we could observe fresh mass yields of 9,642; 22,989; 25,$127 ; 23,531$; and $25,673 \mathrm{~kg} \mathrm{ha}^{-1}$ for corn plants $2,4,6,8$, and $10 \mathrm{~m}$ away from eucalyptus plants, respectively. Despite the periods of water deficiency (Figure 1) and the degraded pasture history, which is under recovery, corn production was considered satisfactory. The fresh mass yield data (Figure 5) were similar to those found by Viana et al. (2010) in an ILPF system conducted in the state of Minas Gerais, with a $(3 \times 2)+20$ m arrangement, obtaining a yield of $25,460 \mathrm{~kg} \mathrm{ha}^{-1}$.

Figure 5. Fresh mass yield $\left(\mathrm{kg} \mathrm{ha}^{-1}\right)$ of corn forage for plants $2,4,6,8$, and $10 \mathrm{~m}$ away from eucalyptus trees in an agrosilvopastoral system.

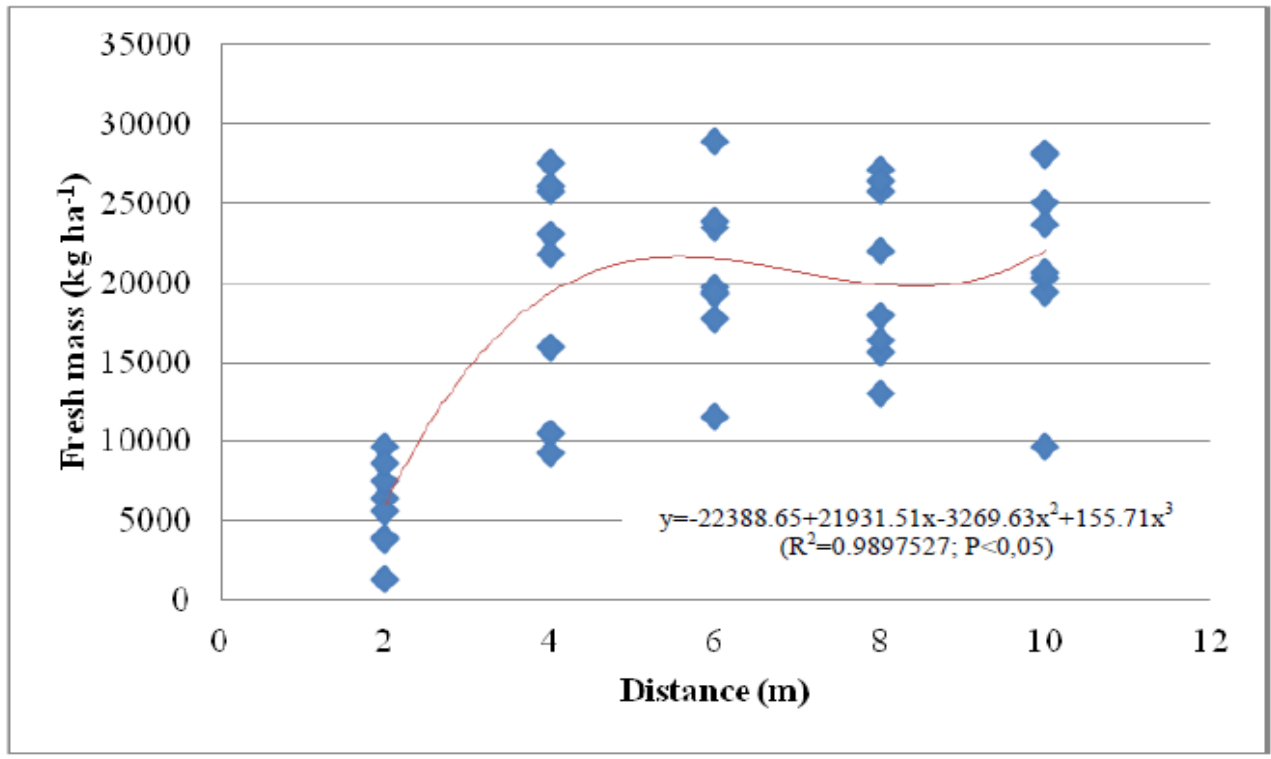


The relationship between the dry mass yield of corn forage and the distances from the tree rows was best expressed by a cubic equation, wherein the lowest yield was observed for plants $2 \mathrm{~m}$ far (Figure 6). However, the plants located at the other distances showed similar results. From the regression equations in Figure 6, we noted the following results 2,$456 ; 6,100 ; 7,038 ; 6,901$; and $7,321 \mathrm{~kg} \mathrm{ha}^{-1}$ for the distances $2,4,6,8$, and $10 \mathrm{~m}$, respectively. We may state that the amount of light intercepted and competition for water and nutrients in plants closer to the eucalyptus trees $(2 \mathrm{~m}) \mathrm{might}$ have affected corn forage yield. These findings are in agreement with those found by Mendes et al. (2013) when studying an agrosilvopastoral system with rows of pau-branco (C. oncocalyx) (200 trees $\mathrm{ha}^{-1}$ ) in the Brazilian semi-arid region (Caatinga). These authors encountered low contents of corn shoot and ear dry matter for plants $1 \mathrm{~m}$ away from the trees; however, the plants located $4 \mathrm{~m}$ away from trees produced dry matter amounts similar to those of control treatment (no trees). Studying similar arrangements to the ones studied here $[(3 \times 2)+20$ $\mathrm{m}]$, Viana et al. (2010) obtained a corn dry mass yield of 7,830 $\mathrm{kg} \mathrm{ha}^{-1}$. In a similar arrangement with two eucalyptus rows, Gontijo Neto et al. (2014) reported superior amounts of corn dry mass for silage, with an average yield of $10,840 \mathrm{~kg} \mathrm{ha}^{-1}$ after three years of evaluations, in Minas Gerais state (Brazil).

Figure 6. Dry matter yield $\left(\mathrm{kg} \mathrm{ha}^{-1}\right)$ of corn forage for plants $2,4,6,8$, and $10 \mathrm{~m}$ away from eucalyptus trees in an agrosilvopastoral system.

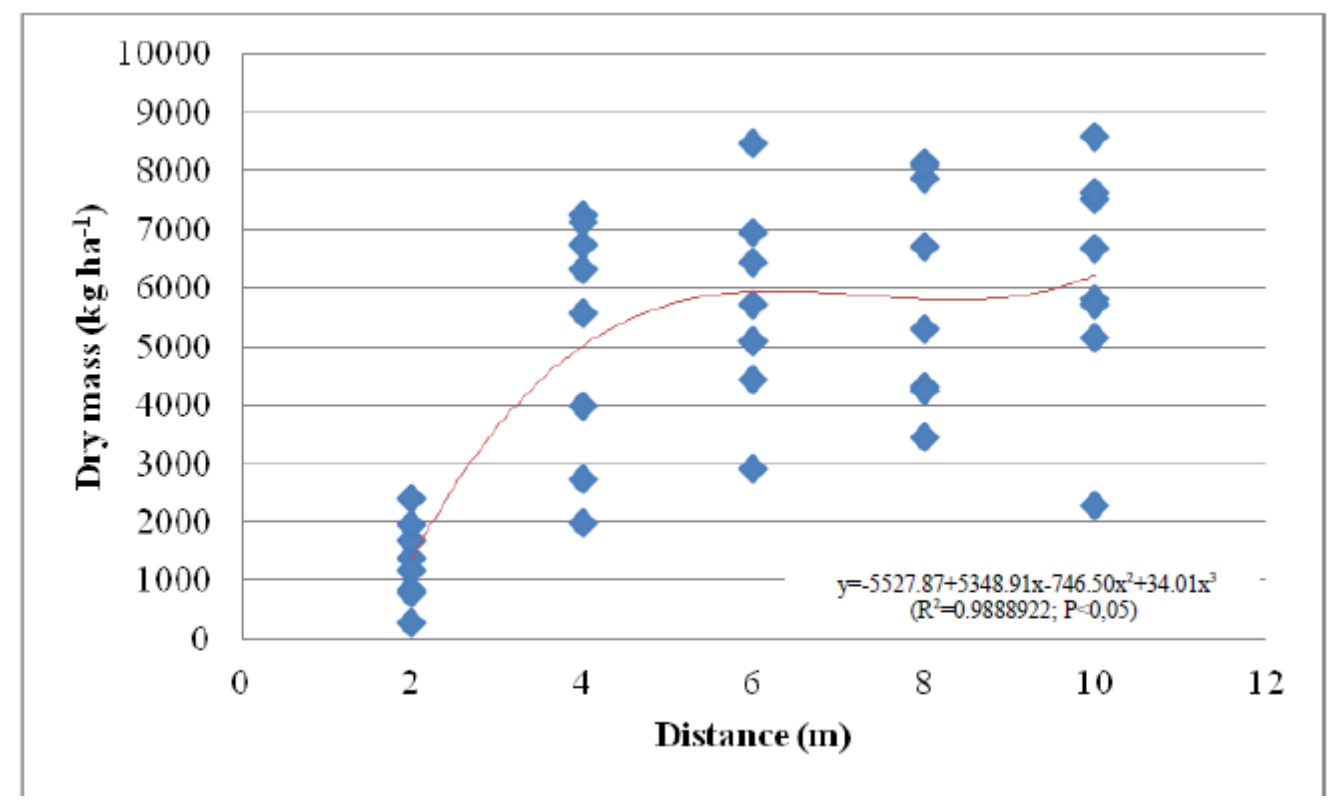

The arrangement of eucalyptus trees into 1 or 3 rows had no influence on corn forage yield, both fresh and dry mass, in the agrosilvopastoral systems studied here, with averages of $17,757 \mathrm{~kg} \mathrm{ha}^{-1}$ and $4,872 \mathrm{~kg} \mathrm{ha}^{-1}$, respectively. In addition, the control presented similar yield, being of $19,474 \mathrm{~kg} \mathrm{ha}^{-1}$ and $5,627 \mathrm{~kg} \mathrm{ha}^{-1}$, respectively, with no difference in relation to the evaluated agrosilvopastoral systems.
At harvest, corn forage dry matter content was lower for plants at a distance of $2 \mathrm{~m}$ from the trees (Figure 7). Overall, the closer the plants were to the trees, the higher the moisture content, which must be attributed to the low temperatures provided by the wind barrier built by the trees. 
Figure 7. Dry matter content of corn forage for plants 2, 4, 6, 8, and $10 \mathrm{~m}$ away from eucalyptus trees in an agrosilvopastoral system.

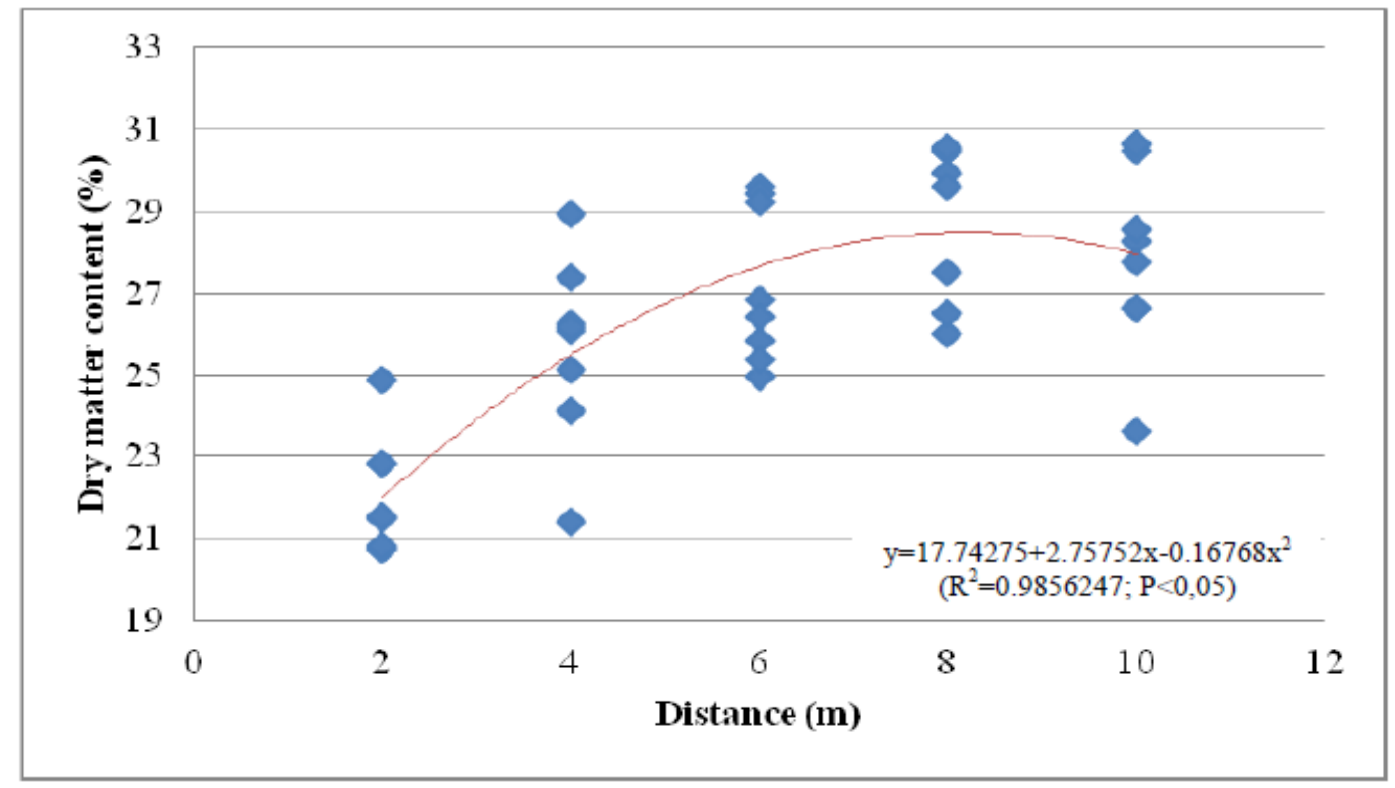

Regarding corn dry matter, control and the evaluated agrosilvopastoral systems were significantly different $(\mathrm{P}<0.05)$, which increased on average $28.61 \%$ for the first group and $26.32 \%$ for the second. Thus, plants in agrosilvopastoral systems are more humid since trees help to maintain air humidity and reduce the wind. This reflected on smaller amounts of dry matter in systems with 1 and 3 tree rows if compared to systems with plants under full sun exposure. Tree arrangements containing 1 or 3 rows of trees had no influence on dry matter content, averaging $26.32 \%$.

Corn production and plant height were lower because of a poorly distributed and below average rainfall during the experimental period (Figure 1), reaching critical edaphoclimatic conditions for plant growth. This fact occurred in most of January and February, which is the vegetative growth period and the beginning of flowering, thus directly affecting crop yield and intensifying competition with the grass.

\section{Conclusion}

Corn forage yield and growth are similar in agrosilvopastoral systems with one and three rows of 15-month-old eucalyptus plants and in systems with no trees, except for dry matter content, which is lower in systems containing trees.

Corn intercropped with marandu grass in systems without trees presented higher light interception at corn harvesting, what indicates a larger oil coverage.

Corn forage yield and dry matter content were lower for plants located $2 \mathrm{~m}$ from eucalyptus trees, what might be due to the lower light incidence and a stronger competition for water and nutrients.

\section{References}

ALVARENGA, R. C.; COBUCCI, T.; KLUTHCOUSKI, J.; WRUCK, F. J.; CRUZ, J. C.; GONTIJO NETO, M. M. A cultura do milho na integração-lavoura-pecuária. Sete Lagoas: EMBRAPA-CNPMS, 2006. 12 p. (EmbrapaCNPMS. Circular técnica, 80). 
CARNEVALLI, R. A. Dinâmica da rebrotação de pastos de capim-Mombaça submetidos a regimes de desfolhação intermitente. 2003. Tese (Doutorado em Ciência Animal e Pastagens) - Escola Superior de Agricultura Luiz de Queiroz, Universidade de São Paulo, Piracicaba.

COMPANHIA NACIONAL DE ABASTECIMENTO CONAB. Acompanhamento da safra brasileira de grãos: Safra 2013/2014. Brasília: Conab, 2014. Available at: $<$ http://www.conab.gov.br>. Accessed at: 22 dec. 2014.

FERREIRA, E. B.; CAVALCANTI, P. P.; NOGUEIRA, D. A. ExpDes.pt: experimental designs package (Portuguese). R package version 1.1.2. [S.1.: s.n.], 2013. Available at: <https://CRAN.R-project.org/package $=$ ExpDes.pt $>$ Accessed at: 1 oct. 2014.

GONTIJO NETO, M. M.; VIANA, M. C. M.; ALVARENGA, R. C.; SANTOS, E. A.; SIMÃO, E. P.; CAMPANHA, M. M. Sistemas de integração lavourapecuária-floresta em Minas Gerais. Boletim da Indústria Animal, Nova Odessa, v. 71, n. 2, p. 183-191, 2014.

MACEDO, R. L. G.; BEZERRA, R. G.; VENTURIN, N.; VALE, R. S.; OLIVEIRA, T. K. Desempenho silvicultural de clones de eucalipto e características agronômicas de milho cultivados em sistema silviagrícola. Revista Árvore, Viçosa, MG, v. 30, n. 5, p. 701-709, 2006.

MENDES, M. M. S.; LACERDA, C. F.; CAVALCANTE, A. C. R.; FERNANDES, F. E. P.; OLIVEIRA, T. S. Desenvolvimento do milho sob influência de árvores de pau-branco em sistema agrossilvipastoril. Pesquisa Agropecuária Brasileira, Brasília, v. 48, n. 10, p. 13421350, 2013.

NEVES NETO, D. N.; SANTOS, A. C.; SOUSA, L. F.; SANTOS, P. M.; ARAUJO, A. S.; ALENCAR, N. M. Establishment of Urochloa brizantha cultivars intercropped with different cereal grains. Semina: Ciências Agrárias, Londrina, v. 36, n. 5, p. 3353-3368, 2015.
OLIVEIRA, I. P. Palhada no sistema Santa Fé. Goiânia: Embrapa, CNPAF, 2001. 4 p. (Embrapa, CNPAF. Informações Agronômicas, 93).

PERIN, R.; SOUZA, J. N.; MORAIS, R. R. de; TONATO, F.; ROCHA, R. N. C.; FONTES, J. R. A. Efeito do sombreamento na produtividade de milho em sistemas agrossilvipastoris. In: CONGRESSO BRASILEIRO DE SISTEMAS AGROFLORESTAIS, 8., 2011, Belém. Anais... Belém: SBSAF: Embrapa Amazônia Oriental: UFRA: CEPLAC: EMATER: ICRAF, 2011. CD-ROM.

QUINTINO, A. C.; ALMEIDA, R. G.; ABREU, J. G.; MACEDO, M. C. M.; BARROS, J. S.; ARANHA, A. S.; BRAGA, M. P. P. Produtividade de milho em sistema de integração lavoura-pecuária-floresta. In: JORNADA CIENTÍFICA EMBRAPA GADO DE CORTE, 9., 2013, Campo Grande. Anais... Campo Grande: Embrapa Gado de Corte, 2013. p. 14-15. (Embrapa Gado de Corte. Documentos, 204).

R CORE TEAM - R. A language and environment for statistical computing. Vienna: R Foundation for Statistical Computing, 2014. Available at: <http://www.R-project. org/>. Accessed at: 5 sept. 2014.

RAIJ, B. V.; CANTARELLA, H.; QUAGGIO, J. A.; FURLANI, A. M. C. Recomendação de adubação e calagem para o Estado de São Paulo. 2. ed. Campinas: IAC, 1997. 285 p. (IAC. Boletim técnico, 100).

VIANA, M. C. M.; GUIMARÃES, C. G.;ALVARENGA, R. C.; FREIRE, F. M.; FONSECA, R. F.; VIANA, M. S.; TEIXEIRA, F. F. Produção do milho para silagem em sistema agrossilvipastoril em diferentes arranjos estruturais do eucalipto. In: CONGRESSO NACIONAL DE MILHO E SORGO, 28., 2010, Goiânia. Anais... Goiânia: ABMS, 2010. CD-ROM. 